\title{
Anthós
}

$5-2020$

\section{Arthur Clennam's Navigation of Social and Physical Setting in Little Dorrit}

Danielle Jochums

Portland State University

Follow this and additional works at: https://pdxscholar.library.pdx.edu/anthos

Part of the Literature in English, British Isles Commons Let us know how access to this document benefits you.

Recommended Citation

Jochums, Danielle (2020) "Arthur Clennam's Navigation of Social and Physical Setting in Little Dorrit," Anthós: Vol. 9: Iss. 1, Article 3.

https://doi.org/10.15760/anthos.2020.9.1.3

This open access Article is distributed under the terms of the Creative Commons Attribution-NonCommercialShareAlike 4.0 International License (CC BY-NC-SA 4.0). All documents in PDXScholar should meet accessibility standards. If we can make this document more accessible to you, contact our team. 


\section{Arthur Clennam's Navigation of Social and Physical Setting in Little Dorrit}

Danielle Jochums

In the 2003 Companion to Little Dorrit, author Trey Philpotts prefaces his annotative endeavors by commenting, "the 'world' of Dickens passed away more than a century ago, and our perceptions and interpretations of his works can be sharpened by our having recalled for us a precise context or piece of information." While the second part is uncontestable as the need for historical context is immediately clear to any modern reader, the first part evokes a more uncertain topic of speculation: to what, exactly, the term "Dickens' world" refers. Certainly, Charles Dickens is unequivocally tied to the period in which he wrote. The word Dickensian brings to mind settings of Victorian squalor inhabited by repulsive characters. Dickens' lived experiences of child labor and residence in a Debtor's prison epitomizes the plight of the working class in Victorian England. Like many of his other works, Little Dorrit elucidates the horrid conditions of Dickens' childhood as its characters go through the same settings and circumstances as he did in his boyhood. It is for this reason that the first volume of Little Dorrit, the focus of the current analysis, is aptly titled "Poverty."

However, the narrative of Little Dorrit includes more than impoverished settings and absolutely destitute characters. Little Dorrit herself is a young woman who lives with her family in The Marshalsea prison, an infamous London debtor's prison. Little Dorrit's father, as a longtime resident of the prison, enjoys a certain prestige within its walls, being referred to as the 'Father of the Marshallsea.' While, as a debtor, Mr. William Dorrit is not able to leave the prison, his adult children are allowed to move freely in and out of the prison. Little Dorrit thus provides the source of income for both her father and herself through her sewing work outside of the prison. One individual who she sews for is an austere widow and businesswoman, Mrs. Clennam, who shows an unusual soft spot for the hardworking young woman. This unusual kindness is taken up 
by her adult son, Arthur Clennam, who recently returned from working abroad in China. Upon discovering that Little Dorrit lives in the Marshalsea, he decides to act as the benefactor of Little Dorrit and her family. He futilely attempts to advocate for the Dorrits in the confounding bureaucracy that relegates them to their situation before reallocating his energy to helping the Dorrits by reestablishing himself in London, forming friendships with the Meagles, a wealthy manor-owning family, and forming a business partnership with Daniel Doyce, an inventor who has also suffered under the rule of English bureaucracy.

Through Little Dorrit's struggles in and out of the Marshalsea and Arthur Clennam's process of refamiliarization with London, Little Dorrit portrays almost every echelon of British society, exploring both the greater London area as well as dabbling into settings in mainland Europe. Dickens devotes a tremendous amount of time revealing his settings throughout the novel. To revisit the notion of Dickens' world, we must consider that, like any writer of fiction, Dickens is carefully curating reality to fit his narrative aims. Some settings of Little Dorrit follow through on the expectation for Dickens to report urban Victorian squalor. However, some settings seem too opulent or too sensationalized, filled with characters too comical or haughty, to accurately depict the realities of the Victorian world. Dickens' world is not synonymous with the Victorian world. In the scenes and settings of Little Dorrit, Dickens constructs a warped replication of the time he lived in, with cutting satire to critique the spaces of every level of the social stratum.

In his description and development of locations, Dickens is able to empress the reader with space that is not just classed, but also value-laden. Dickens requires a guide to lead the reader through the complex series of microcosms that forms the world in Little Dorrit. The primary guide that Dickens selects is not Little Dorrit herself, but Arthur Clennam, who, as a bourgeoisie male, is able to weave in and out of various social circles and physical settings. As the reader journeys with Arthur through a plethora of ornate social scenes, it 
is possible to observe the clear interaction between characters and their settings. It is a more difficult task to appreciate and evaluate the nuances of Arthur's relationship with place, especially when accounting for the additional nuance of narration and tone. In any case, it seems that Arthur Clennam's navigation and judgement of London's locations and his adaptability to those locations develop the prudence and the strength of moral character that define the core of his characterization and identity. Furthermore, Arthur's interaction with setting teaches the reader how to evaluate society both in and out of the novel.

In order to understand how Arthur interacts with setting, one must first evaluate the setting of Arthur's origin, the spatial nurture to his nature. The reader's first experience in the London of Little Dorrit is a depiction of all that is dreary and all that best remains in the shame of shadow. This ominous energy does not end once Arthur returns to the home of his boyhood. In fact, it is quite the opposite. Arthur, observing his former home for the first time in years, notes:

The old articles of furniture were in their old places; the Plagues of Egypt, much the dimmer for the fly and smoke plagues of London, were framed and glazed upon the walls. (...) There was the large, hard-featured clock on the sideboard, which he used to see bending its figured brows upon him with a savage joy when he was behind-hand with his lessons, and which, when it was wound up once a week with an iron handle, used to sound as if it were growling in ferocious anticipation of the miseries into which it would bring him. (Dickens $72-73$ )

Through this excerpt, the reader sees the Clennam household as the epitome of grim stagnation. Despite a twenty-year-long absence, the house has not changed or evolved at all. The unchanging nature of the setting causes Arthur to slip back into the memories and perspective of his youth, a youth characterized by solemnity and fear. This imagery is exemplified in the 
personification of the clock, representing not just the passing of time, but also the structure and imperviousness that that time-keeping symbolizes. This clock is described in threatening language, with Dickens selecting words for the clock's characterization such as "growling" and "ferocious," demonstrating the dread and fear that underscored Arthur's childhood. This setting of dread would not be complete without the imposing matriarch, Mrs. Clennam. Before sending Arthur to his childhood home, Dickens narrates:

There was the interminable Sunday of his nonage; when his mother, stern of face and unrelenting of heart, would sit all day behind a Bible - bound, like her own construction of it, in the hardest, barest, and straitest boards, with one dinted ornament on the cover like a drag of a chain, and a wrathful sprinkling of red upon the edges of the leaves - as if it, of all books! Were a fortification against sweetness of temper, natural affection, and gentle intercourse. There was the resentful Sunday of a little later, when he sat down glowering and glooming through the tardy length of the day, with a sullen sense of injury in his heart, and no more real knowledge of the beneficent history of the New Testament than if he had been bred among idolaters. There was a legion of Sundays, all days of unserviceable bitterness and mortification, slowly passing before him. (Dickens 69)

Through this quote, the reader is presented with a strong characterization of Mrs. Clennam and the cold-hearted Christianity in which she raised Arthur. She establishes herself and her household on morality, justice, and perseverance, pillars completely unchanging, even with the creation of a second half of the Bible. Her relentless enforcement of her supposedly Christian inclemency burdened her son, the many unbearable Sundays forming a legion of torment for him. The usage of "legion" here also acts as an allusion to the New Testament that Mrs. Clennam ignores, as in the gospel Jesus exorcises men of demons who report that their name is Legion, for they are many. Just as the demons possessed 
the men in this gospel tale, Mrs. Clennam's heartless derivative of Christianity takes the joy from Arthur's boyhood.

In addition to his usage of allusion, Dickens uses a disparaging tone to condemn Mrs. Clennam's Pharisee-like ways, emphasizing the negative aspects of her character and her religious practices through heavy implicature and irony as well as the strong use of literary devices such as repetition in order to reinforce his perspective. Through this depiction of the harsh home and cold-heart of Mrs. Clennam, we understand the circumstances of Arthur's upbringing as being rigid and religious. The Clennam household is a loveless void dedicated to suffocating and smiting everything not ordained by the god of love.

Arthur himself upholds the Biblical values of morality and justice, however, he does not practice the same hypocrisy; instead, he enacts the values with a warmth and kindness that stems from a sincere devotion to upholding what is right. In this way, Arthur is able to be a protector and embody the new virtues of the New Testament despite the fact that he was raised exclusively on the messages of hellfire and damnation from the Old Testament. This is seen in particular as he seeks to right his family's wrong and as he vows to assist Little Dorrit in any way possible.

It is important to note here that, from this early point in the story onward, Arthur's actions and attitudes fall in line with the views implied by the tone and voice of the narrator. This is seen in Arthur's reluctance to return to his boyhood home, in accordance to the disparaging tone of the narrator. This suggests to the reader that Arthur's moral compass points due north, fostering a sense of trust as well as creating the foundation of the reader's understanding of Arthur's character. This true morality, one that is kind and understanding, is at the core of Arthur's identity.

Another core part of Arthur's character introduced in this early chapter is perhaps the most important and least obvious of Arthur's qualities: Arthur's 
adaptability. Although we see the young Arthur as being tormented and beat down by the environment he was raised in, he still begrudgingly marches along in this legion of Sundays. This evidences a quality that will be absolutely indispensable to Arthur throughout the rest of the book; he is extremely adept at navigating spaces. He can quickly observe the dynamics at play in a setting and understand how to best fit himself into those dynamics. In his youth, this took the form of his subservience and obedience to the beliefs of his family; in his late adulthood, this takes the form of observation, adaptation, and action as he works to build a life for himself and to act as a protector of innocence and justice.

The most essential location where these aforementioned traits come into play is one of the most pivotal locations in the whole novel: The Marshalsea Prison. It is evident that Arthur's kindness and morality are the impetuses that drive him to seek out more information on Little Dorrit and to decide to act as her friend and protector. However, it is Arthur's other qualities, his perceptiveness and adaptability, that truly shape the reader's experience of the Marshalsea. In the 1979 essay "Guilt, Authority, and the Shadows of Little Dorrit," Elaine Showalter explains that "Marshalsea prisoners were allowed a great deal of leeway in maintaining their personal fictions of gentility and innocence; they wore no uniforms and suffered none of the penitentiary disciplines of silence and isolation.

This freedom to perform elaborate pretenses is at the center of life in the Marshalsea for the Dorrit family. The Dorrit patriarch and his family uphold their pride by ignoring the reality that Little Dorrit is the breadwinner for the family and instead focusing on the elevated status within the prison William Dorrit enjoys by being considered the Father of the Marshalsea. Arthur is able to perceive this complex social situation he has stepped into and act in accordance to its spoken and unspoken rules, effectively acting in a social scene without upsetting its other players. By adapting himself so that he appears to accept the narrative that they have cultivated about themselves and for themselves, Arthur does not alienate the Dorrits. In return, they do not alienate him. Arthur's ability 
to recognize the complexity of the social situation as well as his ability to actively participate in the illusions and pretenses allows him to interact with the Dorrit family.

The Marshalsea is just the first example of Arthur's ability to play along with people's pretenses. In order to show us the prevalence of pretense on every level of the social hierarchy, Dickens places Arthur Clennam among the "real" gentility in Hampton Court. Due to Arthur's social position and friendship with the Meagles, he is invited into Hampton Court, a location and crowd that deviates significantly from the locations featured in other parts of the novel. At the time in which Little Dorrit takes place, Hampton Court, the former primary royal residence for the British monarchy, was subdivided into apartments and granted to people of gentility that were too poor to reside elsewhere. Dickens wastes no time in narrating his exact thoughts about these residents of Hampton Court in a lengthy descriptive paragraph, describing:

The venerable inhabitants of that venerable pile seemed, in those times, to be encamped there like a sort of civilized gipsies. (...) Callers looking steadily into eyes of their receivers, pretended not to smell cooking three feet off; people, confronting closets accidently left open, pretended not to see bottles; visitors with their heads against a partition of thin canvas, and a page and a young female at high words on the other side, made to believe to be sitting in a primeval silence. There was no end to the small social accommodation-bills of this nature which the gipsies of gentility were constantly drawing upon, and accepting, one another." (Dickens 349)

Through this description and other lengthy descriptions, the reader is able to gather a good sense of the setting of Hampton Court, although Arthur spends a very small portion of the novel there. The residents of these retrofitted apartments share many things in common with Hampton Court itself; both are remnants of 
aristocracy, having suffered a fall in status as English society experienced the ramifications of the rise of industrialization in urban centers, especially in London. However, the memory of gentility in Hampton Court preserves a sense of pride amongst the establishment and its residents. Hampton Court serves an oasis for its inhabitants, their refinement lost, but their pride not yet lost. Because of the mutuality of their circumstances, they live under an unspoken agreement to respect each other's feigned respectability, ignoring all of the visible signs of their descent from ascendancy that Dickens details.

Just as the Hampton Court Bohemians accept one another, Arthur also accepts them and accommodates their social pretenses. Despite the fact that Arthur seems to be in agreement with the narration, understanding the facades and pretenses that the Hampton Court residents keep up, he acts as a gracious guest. Additionally, Arthur can see the lack of virtue apparent in the characters surrounding him. He is able to see through each of his fellow dinner guests. Arthur's thoughts toward them guide the reader to see the full shallowness of the upper classes. In turn, Arthur's judgements allow the reader to see what qualities Arthur deems important and which he deems unimportant. For instance, we see that Arthur does not hold social status as an attribute that defines an individual first and foremost. Most importantly, Arthur's insights and interactions at Hampton Court allow the reader to see a parallel to the Marshalsea; we realize that pretenses may exist everywhere and in every class.

While Arthur Clennam is able to move fairly passively through the previously discussed settings, he is also able to immerse himself and to interact fully with the natural world, as evidenced through his visits to the Meagles in their country estate. In the passages describing the location of Twickenham, Dickens paints a landscape of serenity, which in turn sheds a peaceful light over Arthur despite the uncertainty in his life. This is clearly seen in the following passage recounting Arthur's walk from the city to Twickenham: 
He went by Fulham and Putney, for the pleasure of strolling over the heath. It was bright and shining there; and when he found himself so far on his road to Twickenham, he found himself a long way on his road to a number of airier and less substantial destinations. They had risen before him fast, in the healthful exercise and the pleasant road. It is not easy to walk alone in the country without musing upon something. And he had plenty of unsettled subjects to meditate upon, though he had been walking to the Land's End. (Dickens 23)

In this excerpt, the reader sees Arthur, up to this point a thoroughly metropolitan man, enjoying a pleasant and pensive stroll out of the congestion of the city into the tranquility of the country. He is able to savor the sights and details along his journey to his destination, while also using the calm to recenter his thoughts about the quandaries of his life. Through idyllic descriptive passages of the country such as this, Dickens submits to the pastoral tradition. In her 1979 essay, "Dickens and the Art of the Pastoral," Rosemarie Boder asserts:

As a metaphor for a moral position, nature was as important to Dickens as it was to any of the great Victorian social writers. We need only think of the many instances in which the word 'unnatural,' or metaphors of distorted natural process appear in Dickens' work as figures for diseased social and personal conditions; or of the moral territory staked out in those early pastoral landscapes, where traditional humane values are said to flourish.

While Dickens' use of the country as a metaphor for moral position and traditional humane values is indeed apparent, his submission to the pastoral tradition is more complicated than it first may seem, especially when viewing it in relation to Arthur's character analysis. In order to understand why, we must establish how Dickens encourages the reader to view the settings and characters present in his writing. Dickens engineers a narrative world that is more than 
flowery descriptions and heavy-handed implicature; it is a highly interconnected network of character, setting, and narrative tone. However, in analyzing Twickenham, we realize how tangled this network can be. In particular, we come across the following case of circular reasoning: we know that the country is morally good because Arthur approves of it; we know that Arthur is morally good because he approves of the country.

Once Dickens utilizes this country setting to establish Arthur as a moral character, paradoxically yet firmly, he leads the readers to Doyce's factory in order to witness how this pastoral wholesomeness can exist in an urban context. Like Arthur, Daniel Doyce is presented in his visits to Twickenham as a sensible character with an appreciation for nature. However, both Arthur Clennam and Daniel Doyce are far from being wealthy noble estate owners; they are city dwellers with a factory to run. One might originally anticipate that Dickens would feel an obligation to paint any factory owner unfavorably; however the essay "Dickens and the Factories" written in 1971 by Patrick Brantlinger explains, "the factory of Doyce and Clennam, despite the generally increased gloom of Little Dorrit, is apparently a place of light and hope in the midst of social wilderness." Furthermore, Brantlinger notes that "the relations between Doyce and his men are entirely harmonious." This harmony is indicative of what Dickens is attempting to illustrate through Bleeding Heart Yard in Little Dorrit. Instead of bitterly criticizing factories, he is giving an example of how factories could be in an ideal world with real practical and moral people in charge. Rather than, like the bureaucratic mire of the Circumlocution Office, showing society how not to do it, Dickens is showing us how to do it. Arthur Clennam and Daniel Doyce are examples of ideal city men, men who can live in the urban environment without succumbing to its vices. 
Through Arthur Clennam's navigation of physical and social space, Dickens develops his protagonist as being perceptive and flexible as well as being grounded in morality, prudence, and compassion. Arthur is a highly adaptive character in more than one respect. He is adaptive throughout the narrative by changing in order to fit into the social circumstances in which he finds himself. $\mathrm{He}$ is also adaptive in that Dickens is able to make adjustments to the use of his character in order to create various social commentaries. At times, Dickens simply places Arthur into new locations and social spaces so that readers will have the chance to experience all the narrative has to offer in that new setting. Other times, when Arthur moves into a new setting, he is actively working as an example to illustrate Dickens' ideals. Regardless of what environment Arthur is in or how Arthur interacts with that environment, Arthur is the key to revealing Dickens' thoughts on place and class. Arthur's integrity and New Testament values, as well as his pastoral purity of heart and mind, cause the reader to trust him as he leads them through the chaos of Dickensian London. His character is the only constant that prevents the reader from getting lost in the abundance of settings and snide in the story. Arthur's complex relationship with his context also allows the reader to truly appreciate the impact that location and social circumstance has on any individual, not just the comical and exaggerated secondary characters. This teaches the reader to evaluate the effect that setting has on any person, even those outside Dickens' world. After learning to trust Arthur as we follow him in his navigation of his universe, we learn to trust ourselves in our own navigations of our current world. In this way, Dickens masterfully utilizes his protagonist to cultivate social awareness and critical thinking in the reader that transcends location or time period. 
To revisit the introduction of the present analysis, Dickens' world did not "pass away" more than a century ago. Dickens' world is not urban squalor or Victorian society. Dickens' world is instead a curation of the present meant to highlight the best and worst features of society and humanity. In the midst of this curation, Arthur Clennam's character is constructed to interact with Dickens' settings in a way that provides hope that, in any time period, virtue can be preserved as long as we evaluate our environments and maintain our values as we adapt to them. 


\section{References}

Bodenheimer, Rosemarie. "Dickens and the Art of Pastoral." The Centennial Review, vol. 23, no. 4, 1979, pp. 452-467.

Brantlinger, Patrick. "Dickens and the Factories." Nineteenth-Century Fiction, vol. 26, no. 3, Dec. 1971, pp. 270285. https://doi .org/10.1525/ncl.1971 .26.3.99p0093r. Accessed March 2020 .

Dickens, Charles. Little Dorrit. Penguin Books, 1985.

Philpotts, Trey. The Companion to Little Dorrit. Helm Information Ltd, 2003. Showalter, Elaine. "Guilt, Authority, and the Shadows of Little Dorrit." Nineteenth-Century Fiction, vol. 34, no. 1, June 1979. https://doi .org/1 0.1525/ncl.1979.34.1.99p0061g. Accessed March 2020. 